\title{
The Gulf of Lions: An overview of recent studies within the French 'Margins' Programme
}

\author{
S. Berné ${ }^{a^{*}}$ and C. Gorini ${ }^{b}$ \\ alfremer, Département Géosciences Marines, BP 70, 29280 Plouzané Cedex, France \\ 'Université de Lille 1, UMR 8110, SN5, 59665 Villeneuve d'Ascq cedex, France \\ *: Corresponding author : sberne@ifremer.fr
}

\begin{abstract}
Within the French 'Margins' Programme (Groupement de Recherches 'Marges', or 'GDR Marges'), The Gulf of Lions was selected as a key area where scientists specialized in complementary aspects of geosciences (structural geology, tectonics, stratigraphy, sedimentology, various aspects of modeling) work together in order to better understand the processes that control the formation and evolution of continental margins. A key objective was to link offshore data (that mainly consist of seismic data and few wells) and onshore studies (mainly based on well and field data). This special edition of Marine and Petroleum Geology on the Gulf of Lions presents some of the main results obtained during three years of research by the group 'GDR Marges-Golfe du Lion'.
\end{abstract}

Keywords: Gulf of Lions, 'Margins' Programme, geosciences, modeling 


\title{
The Gulf of Lions: an overview of recent studies within the French "Margins" Programme
}

\author{
S. Berné ${ }^{\mathrm{a}}$ and C. Gorini ${ }^{\mathrm{b}}$ \\ afremer, Département Géosciences Marines, BP 70, 29280 Plouzané Cedex, France. \\ sberne@ifremer.fr \\ ${ }^{b}$ Université de Lille 1, UMR 8110, SN5, 59665 Villeneuve d'Ascq cedex, France. \\ gorini@univ-lille1.fr
}

Within the French "Margins” Programme (Groupement de Recherches "Marges”, or GDR Marges”), The Gulf of Lions was selected as a key area where scientists specialized in complementary aspects of geosciences (structural geology, tectonics, stratigraphy, sedimentology, various aspects of modeling) work together in order to better understand the processes that control the formation and evolution of continental margins. A key objective was to link offshore data (that mainly consist of seismic data and few wells) and onshore studies (mainly based on well and field data). This special edition of Marine and Petroleum Geology on the Gulf of Lions presents some of the main results obtained during three years of research by the group “GDR Marges-Golfe du Lion”.

The Gulf of Lions is a passive margin in the NW Mediterranean Basin, bounded to the SW by the Cap Creus canyon, and by the Cassidaigne canyon to the NE (Fig. 1). It formed by Oligocene-Aquitanian rifting followed by the opening of a micro-ocean separating the Corsica-Sardinia block from the southern French margin (Le Pichon et al., 1971; Séranne et al., 1995). Because of the young age of this passive margin, its subsidence rate and the 
associated accommodation space for sediments are significant. As a result, a thick (up to $2 \mathrm{~km}$ at the shelf edge and $10 \mathrm{~km}$ in the deep basin) pile of sediment accumulated during the Neogene.

Interpretation of data from the Oil and Gas industry (Mauffret et al., 2001) has evidenced that the Upper Miocene tectonics was characterized by normal faults that were superimposed onto pre-rift structures in the Oligocene-Aquitanian basement and by vertical movements related to an extensional episode clearly recorded in the SW part of the Gulf of Lions. Faults controlled the geometry of Messinian incisions on the shelf, as well as the orientation of Pliocene sedimentary infills. The marked segmentation of the margin and the differential subsidence with creation of accommodation space varying between different segments are illustrated by maps and recent industry seismic lines (LRM cruise, Total) (Gorini et al., this volume). They have important impact on Messinian processes and preservation of Plio-Quaternary sequences and depo-centers.

The Messinian salinity crisis (Clauzon, 1974; Hsü et al., 1973) is a unique event in the world, that had major consequences on the structure of Mediterranean continental margins. It also allows us understanding the behavior of sedimentary systems in response to extreme sea-level changes, and to explore how a margin reconstructed during the last ca. 5.3 My. The salinity crisis is at the origin of a unique stratigraphic marker in the sedimentary record, the so-called Messinian erosion surface that is coeval to the deep basin evaporitic sequence. A precise chrono-stratigraphic framework has been established onshore for this event (Gautier et al., 1994; Krijgsman et al., 1999) and can be utilized for regional correlation and margin reconstruction by modeling. The Gulf of Lions is of particular interest for the study of this event, as it is one of the few margins, together with the Nile deltaic margin, where the response of a large fluvial system can be analysed from source to sink. Because the 
continental shelf is relatively broad, a major effect of the sea-level drawdown was an important rejuvenation of fluvial systems, creating a deeply incised network whose morphology is controlled essentially by transverse accidents inherited from the OligoceneAquitanian extensional tectonic phase. Some of these Messinian canyons might have form by regressive erosion along the slope, in relation with resurgences in karstic fluvial systems, similar to the processes described onshore (Gilli and Audra, 2004). The Cassidaigne canyon, to the extreme east of the Gulf of Lions (Fig.1), might be such an example, as well as features described in the Western Gulf of Lions by Gorini et al., (this volume).

Along the continental rise, detrital cones similar to alluvial fans formed at the outlet of major fluvial systems (Lofi et al., 2003). Sage et al. (this volume) have mapped similar detritic bodies on the basis of their acoustic character in the Oristano Canyon (Sardinia). Their results help to better constrain the geometric and stratigraphic relationships between the canyon, the Messinian detritic sediments, and the evaporites in the Provençal Basin.

One of the main consequences of the Messinian salinity crisis was the deposition of very thick evaporitic series in the deep basin (Ryan, 1973). Subsequently, the presence of Messinian salt allowed for vigorous salt tectonics affecting an area located at depths between 1300 and $2400 \mathrm{~m}$ at the base of the margin. Salt tectonics is well visible on morpho-bathymetric maps. It is characterized, from the proximal to the distal areas, by four deformation domains: (1) Upslope, the extensional domain comprises numerous listric normal faults, and only small salt relics are present. (2) The translated domain shows a thicker salt layer and a non-deformed sedimentary overburden. (3) The downslope domain contains one or more synclines and anticlines. (4) In the most distal domain, diapirs have pierced the overburden, forming marked bathymetric highs (Gaullier, 1993). On the continental rise, a major sedimentary feature is the well-known Rhône Deep Sea Fan, fed by a channel connected to the Petit Rhône Canyon (Fig. 
1). During the last glacial period, breaching of the western channel levee around N42 $15^{\prime}$ of latitude led to the abandonment of the southernmost segment of the main channel and to the formation of a recent distal lobe, the Rhône neofan (Torres et al., 1997). These authors considered that the neofan formed during the Holocene, however, very high resolution seismics and piston cores demonstrate that the neofan per se formed during the Last Glacial cycle or later (Bonnel et al., this volume). Only the uppermost sandy turbidites (not sourced from the Rhône) that blanket the top of the neofan are Holocene in age. Reis et al. (this volume) discuss the influence of salt tectonics on the depositional pattern and architecture of the Quaternary deep-water sedimentary systems in the Gulf of Lions. They consider that position of the main depocenters along the rise is influenced by salt tectonics, that created traps for sediment accumulation. The Pyreneo-Languedocian Sedimentary Ridge (Fig. 1) would be, in their interpretation, a deep sea-fan related to the Pyrenean canyons, with buried channel-levee systems indicating a major sediment supply from the Paleo-Cap de Creus canyon. Jalet and Giresse (this volume) propose, however, that the Sète canyon also influenced formation of the ridge during the most recent period. The undulated features that shape the ridge (with an asymmetry indicative of an upstream migration) are interpreted by these authors as sediment waves, on the basis of lithology, morphology, and comparison with similar features from other areas. However, it is possible that salt tectonics produced the initial topography that was maintained by turbidity currents afterward.

The Messinian salinity crisis was followed by the rapid flooding of the Mediterranean Basin during Zanclean times. As a result, the fluvial systems incised during the Messinian drawdown were partly filled, in their upstream portion, by clinoforms forming spectacular Gilbert-deltas all around the French Mediterranean coast (Clauzon et al., 1995), and elsewhere. The important sedimentary flux from the Alps, Massif Central and Pyrénées 
allowed a rapid re-construction of the margin. It took about 5 million years for the shelf edge to reach the position it occupied before the destruction of the margin during the Messinian. This reconstruction is nicely illustrated by a succession of prograding mega-sequences, showing progressive transfer of depo-centers toward the deep basin (Lofi et al., 2003). An important morphologic feature of the modern Gulf of Lions is the dense network of submarine canyons that deeply (up to $1000 \mathrm{~m}$ ) incise the continental slope. It was shown that these canyons are not genetically linked to the subaerial Messinian canyons (Berné et al., 1999), but formed progressively since the Middle-Late Pliocene, probably in relation with increasing sea-level changes and sediment supply (Lofi, 2002). However, the processes at the origin of submarine canyons, in the Gulf of Lions as elsewhere, remained some kind of “chicken and egg” problem, some authors favoring the importance of slope failures whereas others gave more importance to the position of fluvial systems. In this volume, the detailed analysis of swath bathymetric and high resolution seismic data allows Baztan et al. to propose a scenario where axial incision, formed during periods of direct connection of rivers to the canyons, triggers lateral slope failure along the major valley of the canyons.

Because of high accommodation created by subsidence at the shelf edge, depositional sequences, including thick prograding wedges have been preserved during the Quaternary. They form a "motif” with steep and low angle clinoforms corresponding to upper (sandy) and lower (muddy) shoreface deposits. Rabineau et al. (this volume) demonstrate that this elementary motif must be attributed to 100 ky glacio-eustatic cycles, and not to higherfrequency cycles as previously proposed (Tesson et al., 1993). As the study area is a stable margin situated far away from former glaciated margins where isostatic rebound is important, these shoreface deposits can be utilized as a "dipstick" of "global” sea-level changes during the Quaternary. This seismic and sequence stratigraphic approach is completed by shallow 
cores, that allow precise correlations, through radio-chronology and pollen studies. The pollens also allow identifying warm Marine Isotope Stages, not detectable on seismic profiles (Beaudouin et al., this volume). Good analogues to the Pleistocene sandy shorefaces of the outer continental shelf can be studied in the modern "highstand" situation. They correspond to the Languedocian coastal "lidos" that were investigated by Certain et al. (this volume) with shallow water seismic equipment. These authors demonstrate that the thickness of the littoral prism is mainly controlled by littoral drift and the distribution of cells of circulation.

In summary, the analysis and interpretation of the sedimentary record in the Gulf of Lions allow us understanding the formation and evolution of the margin, including the tectonic episodes, and the control of global (glacio-eustatism) and regional (climate and ocean circulation) changes on this margin. Future research will require better integration of physical oceanographic processes that are obviously underestimated by geologists for interpreting the stratigraphic record, and, as a high priority, long cores and boreholes. The first aspect is presently covered by the Euro-US “Eurostrataform” project. The drilling/coring aspects are addressed through a group of complementary initiatives, including the PROMESS 1 European project, that drilled, for the first time, the shelf edge/upper slope of the Gulf of Lions in July 2004. In 2003, the “GDR Marges” funded a drilling operation in the deltaic plain that sampled the entire Holocene sequence. An objective for the near future will be to push forward complementary proposals within the Integrated Ocean Drilling Programme, in order to investigate the deep-water portion of the Gulf of Lions. 


\section{Acknowledgements}

The institutes and companies that constitute the "French Margins" consortium include CNRSInstitut National des Sciences de l’Univers, TOTAL, Institut Français du Pétrole (IFP), Institut Français de Recherche pour l'exploitation durable de la Mer (Ifremer), Bureau de Recherches Géologiques et Minières (BRGM), Institut de Recherche pour le Développement (IRD). They all are thanked for their financial support. In addition, TOTAL gave access to recent seismic profiles that greatly improved our understanding of Plio-Quaternary evolution of the margin. Additional support came, for some authors, from the European Community through the Eurostrataform (contract EVK3-2001-00200) and Promess 1 (contract EVR1-CT2002-40024) projects, that both have the Gulf of Lions as a major target. J.P. Mazé re-drafted the figure.

\section{CAPTION}

Figure 1: Morpho-bathymetric map of the Gulf of Lions, displaying major toponymics used in this volume. Based on Berné et al. (2004). Shelf data were compiled from sounding charts of the French Navy (Service Hydrographique de la Marine). Continental slope and rise data are based on swath bathymetric surveys of Ifremer.

\section{References}

Berné, S., Carré, B., Loubrieu, B., Mazé, J.P., Morvan, L. and Normand, A., 2004. Le Golfe du Lion. Carte morpho-bathymétrique. Ifremer, Brest.

Berné, S., Loubrieu, B. and the Calmar scientific party, 1999. Canyons and recent sedimentary processes on the western Gulf of Lions margin. First results of the Calmar cruise. Comptes Rendus de l'Académie des Sciences de Paris, 328: 471-477.

Clauzon, G., 1974. L'hypothèse eustatique et le creusement prépliocène de la vallée du Rhône. Annales de Géographie, 456: 129-140. 
Clauzon, G., Rubino, J.L. and Savoye, B., 1995. Marine Pliocene Gilbert-type fan deltas along the French Mediterranean coast. A typical infill of preexisting subaerial Messinian canyons. Field trip guide book of 16th IAS Regional Meeting of Sedimentology, 23: 145-222.

Gaullier, V., 1993. Diapirisme salifère et dynamique sédimentaire dans le bassin liguroprovencal: données sismiques et modèles analogiques, Université Pierre et Marie Curie, Paris, 327 pp.

Gautier, F., Clauzon, G., Suc, J.P., Cravatte, J. and Violanti, D., 1994. Age et durée de la crise de salinité messinienne. Comptes Rendus de l'Académie des Sciences de Paris, 318(2): 1103-1109.

Gilli, F. and Audra, P., 2004. les lithophages pliocènes de la fontaine de Vaucluse (Vaucluse, France). Un argument pour une phase messinienne dans la genèse du plus grand karst noyé de France. Comptes Rendus Géoscience, 336(16): 1481-1489.

Hsü, K.J., Cita, M.B. and Ryan, W.B.F., 1973. The origin of the Mediterranean evaporites. Initial Reports of the Deep Sea Drilling Project, U.S. Govt Printing Office, 13: 12031231.

Krijgsman, W., Hilgen, F.J., Raffi, I., Sierro, F.J. and Wilson, D.S., 1999. Chronology, causes and progression of the Messinian salinity crisis. Nature, 400(12): 652-655.

Le Pichon, X., Pautot, G., Auzende, J.M. and Olivet, J.L., 1971. La Méditerranée occidentale depuis l'Oligocène. Schéma d'évolution. Earth and Planetary Science Letters, 13(1-2): 145-152.

Lofi, J., 2002. La crise de salinité messinienne: conséquences directes et différées sur l'évolution sédimentaire de la marge du Golfe du Lion, Lille 1, Lille, 260 pp.

Lofi, J., Rabineau, M., Gorini, C., Berne, S., Clauzon, G., De Clarens, P., Tadeu Dos Reis, A., Mountain, G.S., Ryan, W.B.F., Steckler, M.S. and Fouchet, C., 2003. Plio-Quaternary prograding clinoform wedges of the western Gulf of Lion continental margin (NW Mediterranean) after the Messinian Salinity Crisis. Marine Geology, 198(3-4): 289317.

Mauffret, A., Durand de Grossouvre, B., Tadeu Dos Reis, A., Gorini, C. and Nercessian, A., 2001. Structural geometry in the eastern Pyrenees and western Gulf of Lion (Western Mediterranean). Journal of Structural Geology, 23(11): 1701-1726.

Ryan, W.B.F., 1973. Geodynamic implications of the Messinian crisis of salinity. In: D.W. Drooger (Editor), Messinian events in the Mediterranean. Elsevier, Amsterdam, pp. 26-38.

Séranne, M., Benedicto, A., Labaume, P., Truffert, C. and Pascal, G., 1995. Structural style and evolution of the Gulf of Lion Oligo-Miocene rifting: role of the Pyrenean orogeny. Marine and Petroleum Geology, 12(8): 809-820.

Tesson, M., Allen, G.P. and Ravenne, C., 1993. Late Pleistocene shelf-perched lowstand wedges on the Rhône continental shelf. In: H.W. Posamentier, C.P. Summerhayes, B.A. Haq and G.P. Allen (Editors), Sequence stratigraphy and facies associations. IAS Spec. Pub. 18, Blackwell Sci. Pub., Oxford, pp. 183-196.

Torres, J., Droz, M., Savoye, B., Terentieva, E., Cochonat, P., Kenyon, N.H. and Canals, M., 1997. Deep-sea avulsion and morphosedimentary evolution of the Rhône Fan Valley and Neofan during the Late Quaternary (northwestern Mediterranean Sea). Sedimentology, 44: 457-477. 


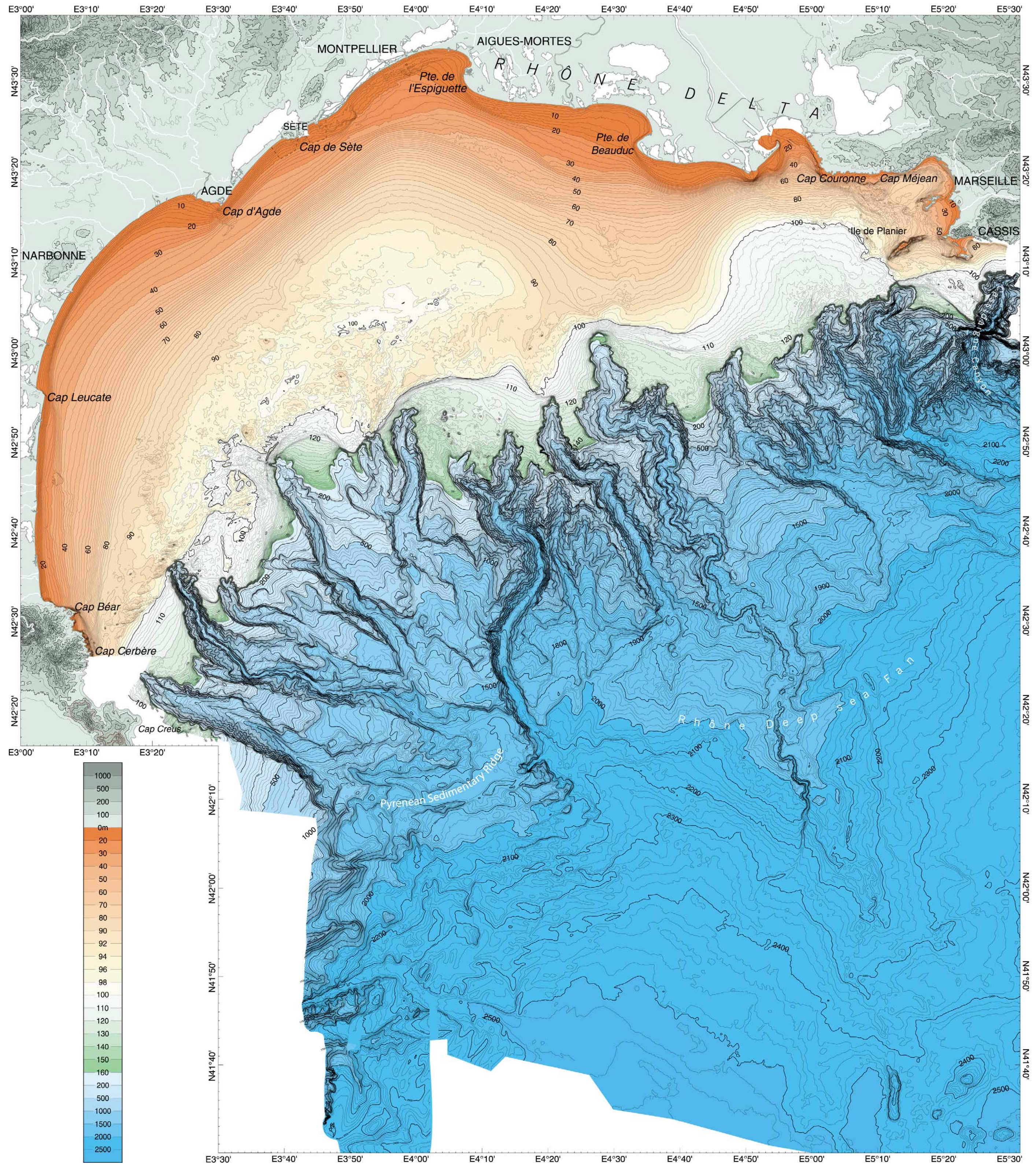

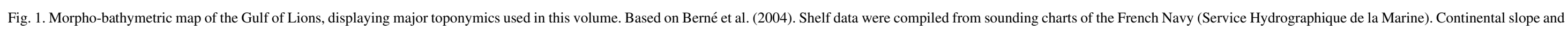
rise data are based on swath bathymetric surveys of Ifremer. 